DEMOGRAPHIC RESEARCH

VOLUME 38, ARTICLE 58, PAGES 1777-1814

PUBLISHED 29 MAY 2018

http://www.demographic-research.org/Volumes/Vol38/58/

DOI: 10.4054/DemRes.2018.38.58

Research Article

Family structure and child development in Chile: A longitudinal analysis of household transitions involving fathers and grandparents

Sarah A. Reynolds

Lia C.H. Fernald

Julianna Deardorff

Jere R. Behrman

(C) 2018 Sarah A. Reynolds et al.

This open-access work is published under the terms of the Creative Commons Attribution 3.0 Germany (CC BY 3.0 DE), which permits use, reproduction, and distribution in any medium, provided the original author(s) and source are given credit.

See https://creativecommons.org/licenses/by/3.0/de/legalcode. 


\section{Contents}

$1 \quad$ Introduction $\quad 1778$

$1.1 \quad$ Fathers $\quad 1778$

$\begin{array}{lll}1.2 & \text { Grandparents } & 1780\end{array}$

$\begin{array}{lll}1.3 & \text { The Chilean context } & 1781\end{array}$

$\begin{array}{lll}1.4 & \text { Contributions to the literature } & 1782\end{array}$

2 Data 1784

$2.1 \quad$ Variable definition $\quad 1784$

$\begin{array}{llr}2.2 & \text { Attrition and sample size } & 1786\end{array}$

$\begin{array}{lll}2.3 & \text { Sample description } & 1787\end{array}$

$3 \quad$ Main analysis $\quad 1790$

$\begin{array}{ll}3.1 & 1790\end{array}$

$\begin{array}{llr}3.2 & \text { Results } & 1792\end{array}$

$4 \quad$ Supporting analyses $\quad 1796$

4.1 Robustness checks for identity 1796

4.2 Does income explain the association between grandparent 1798 separation and reduced vocabulary scores?

5 Discussion $\quad 1798$

$6 \quad$ Acknowledgments 1803

$\begin{array}{ll}\text { References } & 1804\end{array}$

$\begin{array}{lr}\text { Appendix } & 1811\end{array}$ 


\title{
Family structure and child development in Chile: A longitudinal analysis of household transitions involving fathers and grandparents
}

\author{
Sarah A. Reynolds ${ }^{1}$ \\ Lia C.H. Fernald ${ }^{2}$ \\ Julianna Deardorff ${ }^{3}$ \\ Jere R. Behrman ${ }^{4}$
}

\begin{abstract}
BACKGROUND

Adults support child development economically, socially, and emotionally. Household transitions may disrupt these support structures, impacting child development.
\end{abstract}

\section{OBJECTIVE}

We document the large portion of children in Chile that experience biological-father and grandparent household transitions, and test if these transitions are associated with child vocabulary and behavior and if income could be a mechanism behind our findings.

\section{METHODS}

We apply first-differences and lagged-dependent-variable analyses to a large, nationally representative, longitudinal survey of over 5,000 Chilean children.

\section{RESULTS}

We find that children whose mothers separated from their parents' homes within the two years between two survey rounds have worse age-normalized Peabody Picture Vocabulary Test scores than children in households without such transitions. Changes in income per capita do not explain these associations. When fathers enter households between the two survey rounds there is a gain in income per capita but no association between father entrance and child's vocabulary score. Similarly, there is no significant association between fathers separating from the household and child vocabulary, though

\footnotetext{
${ }^{1}$ School of Public Health, University of California, Berkeley, USA. Email: sar48@berkeley.edu.

${ }^{2}$ School of Public Health, University of California, Berkeley, USA. Email: fernald@berkeley.edu.

${ }^{3}$ School of Public Health, University of California, Berkeley, USA. Email: jdeardorff@berkeley.edu.

${ }^{4}$ Department of Economics, University of Pennsylvania, Philadelphia, USA.

Email: jbehrman@econ.upenn.edu.
} 
father departure is associated with lower income per capita. We find no association between household transitions and Child Behavioral Checklist (CBCL) scores.

\section{CONCLUSIONS}

These findings provide evidence that Chilean grandparents promote language development when coresiding with their grandchildren and that Chilean fathers are an important source of household income.

\section{CONTRIBUTION}

Our study examines fathers and grandparents simultaneously. We are able to take the directionality (i.e., movement in or out of the home) of biological father transitions into account.

\section{Introduction}

Better early child development is associated with improved cognitive development and achievement outcomes later in life (Britto et al. 2016; Engle et al. 2007, 2011). Enhanced early cognitive skills, including those related to language, are associated with lower levels of risky behavior and higher labor market earnings later in life (Gertler et al. 2014; Heckman, Stixrud, and Urzua 2006; Walker et al. 2011). Participation in programs designed to improve socio-emotional functioning early in childhood also correlates with academic and labor market earnings later in life (Bierman et al. 2010; Chetty et al. 2011).

Child development outcomes are affected by household composition and by changes to the household resulting from marriage, divorce, death, and other events. Changes in household structure during early childhood can result in insecure attachments and ambiguity in household rules, family relationships, and parental expectations about behavior (Pleck 2007; Hetherington, Bridges, and Insabella 1998). These transitions can influence cognitive development (Mikulincer, Shaver, and Pereg 2003) and can contribute to lower academic performance (Kurdek, Fine, and Sinclair 1995).

\subsection{Fathers}

Longitudinal and sibling studies consistently find that father absence during childhood is correlated with poorer socio-emotional adjustment in children and adolescents and, in the long term, worse mental health as adults (McLanahan, Tach, and Schneider 2013). 
Yet the conclusion that fathers support children's socio-emotional development may not extend into early childhood. Only four of the twenty-three studies on socio-emotional outcomes reviewed by McLanahan, Tach, and Schneider include children younger than age five years, and the results are mixed (2013).

With respect to education, McLanahan et al.'s review indicates that father presence is strongly associated with higher levels of academic achievement, but less strongly with test scores (2013). They do not review any studies on academic achievement for very young children, however, but that omission is unsurprising since young children are not yet in school. More salient are two studies, both using child fixed effects, on family structure and test scores for children younger than age 5. Foster and Kalil find little association between family structure and vocabulary (Foster and Kalil 2007), but Cooper et al. find that more transitions (both coresidence with and dating of mothers' romantic partners, which can include biological fathers) are negatively associated with children's verbal ability at age five (2009). Discrepancies in these results may arise from Foster and Kalil's exploration of family types such as extended and single mother households, but they do not include transitions of romantic partners who do not coreside.

There are a variety of mechanisms by which father absence could influence child development. We discuss three, although our data only allows us to test one. First, income or wealth may explain some of the association between father absence and poor child development outcomes. There is strong evidence that parental union dissolution resulting in father absence is associated with economic disadvantage for children (Amato 2010; McLanahan, Tach, and Schneider 2013; Page and Stevens 2004; Thomson, Hanson, and McLanahan 1994). Engagement may also be a mechanism by which fathers support children's well-being. In a meta-analysis, fathers' engagement (through helping children with homework, listening to children's problems, providing emotional support, and setting limits) is associated with fewer behavioral problems (Amato and Gilbreth 1999), and a randomized intervention of individual and group counseling to improve divorced, non-coresident fathers' relationships with their children and ex-wives reduced behavioral problems among children aged four to twelve (Braver, Griffin, and Cookston 2005). Finally, community social capital available to fathers but not mothers (i.e., more prestigious positions in business, local community governance, or religion) could support child development by providing access to resources or status for the child (Astone et al. 1999; Pleck 2007). However, as it is more difficult to measure social capital there is less research on this mechanism.

Fathers do not only exit families: they also enter them. Around one-third of children in the US are born to unmarried mothers (Curtin, Ventura, and Martinez 2014) and data from the US Fragile Families survey indicates that father entrance is a widespread transition: $28 \%$ of parents who were not cohabitating or married when their 
child was born are cohabitating or married one year after the birth (Carlson, McLanahan, and England 2004). These transitions could have a positive or a negative influence on early child development, given the findings that father presence is generally positive but the stress of household transitions is negative. For example, the number of mothers' romantic transitions (exiting or entering relationships with partners not limited to the children's biological fathers) has been associated with worse children's behavior at age three (Osborne and McLanahan 2007). A review of associations between step-parent presence and child outcomes suggests children with step-parents in the household do worse than children in households where both biological parents are present, but children with step-parents in the household fare similarly academically and behaviorally to children of single mothers (Coleman et al. 2000). However, there is limited evidence regarding how household formation with the child's biological father after the child's birth may relate to the child's welfare.

In summary, theories suggest that fathers' economic resources, engagement, and social capital are supportive of child development, and research finds that father presence is associated with economic benefits but not necessarily with gains in child development. Longitudinal studies on divorce show children with co-resident fathers have better socio-emotional outcomes, but find mixed evidence regarding gains in the cognitive and academic realms. In the subset of studies that examine the effects of divorce from early childhood (under age 5) the results regarding child outcomes are mixed. The family transition of fathers entering households is an important area of new research, which will provide insight on whether the stress of the transitions can be outweighed by the benefits of father presence.

\subsection{Grandparents}

Grandparents can also be important for child development, and their influence could occur through the same mechanisms identified for fathers. For example, grandparents can reduce economic hardship for grandchildren in single-mother-headed families (Mutchler and Baker 2009) and grandmother schooling has been associated with the health of infants of adolescent mothers (Schott et al. 2017). In South Africa and Brazil, analyses of natural experiments indicate grandparent pensions benefit coresident grandchildren (Duflo 2003; Ponczek 2011). A study examining heterogeneity of effects of grandparents by household wealth shows significant benefits of grandparent presence for children born to single mothers in richer households, but no effects for children born to poorer single mothers (Augustine and Raley 2013). On the other hand, several studies find the presence of grandparents to be associated with better child outcomes in single-mother households: Most studies find no association between grandparent 
presence and child outcomes when both parents are in the household (Aquilino 1996; Deleire and Kalil 2002; Dunifon and Kowaleski-Jones 2007; Monserud and Elder 2011). These findings suggest that grandparent impact on child development may be moderated by mothers' partnership status, probably due to the fathers already providing support.

Another moderator may be the cultural role of grandparents' engagement with grandchildren. There is emerging evidence that associations between grandparent coresidence and child outcomes vary by culture. For example, studies on early childhood in the United States find that grandparent coresidence is associated with higher child development scores for Hispanic and Black children, but not for White children (Pilkauskas 2014; Mollborn, Fomby, and Dennis 2010). These discrepancies may arise from different cultural norms influencing how grandparents engage with grandchildren, with some focusing more on nurturing care (stimulation, education, comfort) and others supporting functional care (feeding, cleaning).

Alternatively, grandparent care may be more important in some contexts than in others, even if that care is the same. For example, grandparent coresidence could have more impact in smaller, urban families than in large, extended rural families where children interact with many adults in the home. Similarly, the impact of social capital can differ depending on the community. These mechanisms could explain differences in research on grandparents in Asia. Using an OLS model that compares transitioning families to nontransitioning families in Taiwanese panel data, Pong and Chen (2010) find long-term coresidence with grandparents to be associated with higher cognitive test scores in young adolescents; a recent transition to coresidence confers no such advantage. By contrast, a cross-sectional analysis from rural China suggests that living with grandparents with low levels of schooling compared to the population does not affect children's educational attainment, but living with relatively well-schooled grandparents is significantly associated with a lower likelihood of school dropout (Zeng and Xie 2014).

In comparison to research on fathers, research on the role of grandparents and their influence on children's development is mixed, likely because the grandparental role is more heterogeneous across family situations and cultures. That findings appear to vary by grandparent and mother circumstances, as well as culture, suggests that context is crucial for understanding and interpreting findings.

\subsection{The Chilean context}

Chile is an appropriate context for exploring household transitions and child development due to two demographic characteristics. First, in recent decades stable 
marriage has become less common. In 1999 children born out of wedlock were granted equal child support rights as those born to married couples and in 2004 divorce was legalized with mandated alimony, although prior to that annulments had been common. In contrast to 1970 , when $51 \%$ of women aged $18-45$ were married, only $43 \%$ were married by 2002 (Salinas 2011). By 2012 almost 70\% of Chilean children age 1 year had mothers living out of wedlock; $30 \%$ of children's mothers were not cohabitating with the child's father (Centro Microdatos 2013). Second, Chile has a relatively high teen fertility rate. Though the level of the Chilean adolescent fertility rate was similar to that of the United States in 1960 (respectively 89 and 85 births per 1,000 adolescents ages 15-19), in 2015 Chile's adolescent fertility was 48 births per 1,000 adolescents. This more recent figure is on a par with Colombia and Peru, two middle-income countries, ${ }^{5}$ while the US adolescent fertility rate, at 21 births per 1000, was less than half that of Chile (United Nations, Department of Economic and Social Affairs, Population Division 2015). Young and single Chilean mothers have come to depend on their extended families for support. Similar to other Latin Americans, Chileans value and frequently live in extended family households. Indeed, in Chile and elsewhere in Latin America the portion of intergenerational households is on the rise (Ruggles and Heggeness 2008), as it is in the United States (Dunifon, Ziol-Guest, and Kopko 2014). The increased acceptability of single parenthood allows mothers to continue living with their parents until they are ready to cohabit with the children's fathers or live on their own. Similarly, women choosing to separate from a spouse have more economic and social support than before. Consistently throughout the past decade, over $20 \%$ of mothers of children under age six lived with their parents (see Appendix). In the context of teen pregnancy and more young women entering the labor force (The World Bank 2014) the grandmother role has been transforming in Chile, moving from supportive (such as helping the mother with chores or occasional babysitter) toward primary caregiver (Moreno and Sandoval 2015).

\subsection{Contributions to the literature}

Although there is strong evidence that transitions in household membership are associated with child development, a number of gaps remain in the literature. Most research focuses on associations between a single household member (e.g., father or grandparent) and child well-being. We are aware of only one paper that compares these associations for both grandparents and fathers and examines child health; this paper found father exit, but not grandparent transitions, to be associated with child anemia in Mexico (Schmeer 2013). Using lagged dependent variable models, Schmeer finds the

\footnotetext{
${ }^{5}$ Chile was designated an upper income country by the World Bank in 2012.
} 
lowest risk of child anemia among stable, father-present households; consistent maternal grandparent presence also reduces the risk of anemia, while a maternal grandparent transitioning in or out is not significant. Migration is one of the key reasons for the transitions in Mexico, so exploring transitions in Chile, where migration is less common, is of interest.

Directionality of transitions (i.e., movement in or out of the home) is also a relatively new area of research, as earlier studies focus mainly on father separation or divorce. Additionally, these studies focus on school achievement and adolescent behavior, not on early childhood outcomes. To our knowledge, in the literature only a few studies examine household transitions and behavioral and emotional outcomes during early childhood (Cavanagh and Huston 2006; Mollborn, Fomby, and Dennis 2010; Osborne and McLanahan 2007; Pilkauskas 2014). Compelling evidence suggests that transitions during early childhood may influence child behavior more than transitions in middle childhood (Ryan and Claessens 2013).

Studies of household transitions using natural experiments or instrumental variables $^{6}$ that allow for a causal interpretation are rare in the household structure context (McLanahan, Tach, and Schneider 2013), and actual experiments have not been performed and would have ethical concerns. We use a large, nationally representative, longitudinal survey of Chilean children aged 0-5 years at baseline and apply firstdifferences and lagged-dependent-variable approaches as next-best options to measure the extent to which household transitions of biological fathers and grandparents impact child development outcomes. These methods reduce the concerns about omitted variable bias found in cross-sectional studies.

This rich survey data allows for two particular strengths of our study. First, we are able to take the directionality (i.e., movement in or out of the home) of biological father transitions into account, incorporating a relatively new innovation in the literature, although we are unable to assess the directionality of grandparent transitions because of the small sample size of grandparents entering the household. Second, we examine how two measures of early childhood development (vocabulary and behavioral scores) are associated with these transitions, and we test if change in family income accounts for the associations between household transitions and child outcomes. Based on the literature, we hypothesize that father transitions will be associated with developmental outcomes for children, with exit causing both more transition stress and father absence

\footnotetext{
${ }^{6}$ We are unable to use grandparent death as an instrument because there is no information on why household members are no longer in the household. However, we also postulate that the deaths were few. The average age of grandmothers in the household is 53, below Chilean life expectancy of 58.7 years for females born between 1955 and 1960 (UN data 2015). Furthermore, life expectancy at age 60 years in 2000-2005 was 24 years for Chilean females. There is no statistically significant age difference between grandmothers who stayed in the households and those who leave the households, leading us to conclude that the household changes were not primarily due to grandparent deaths.
} 
problems (e.g., reduced income). However, the impact of entrance may be smaller, although transition stress still occurs, in spite of benefits from father coresidence (e.g., increased income). Since the literature on grandparents is very heterogeneous we do not articulate a hypothesis about grandparent separation and child development.

\section{Data}

We used data from a nationally representative survey of 15,175 children born between January 1, 2006, and August 31, 2009, the Encuesta Longitudinal de Primera Infancia (ELPI, Longitudinal Survey of Early Life - Centro Microdatos 2013). The first round of ELPI was conducted in 2010 among children 0-5 years old, and the second round was conducted in 2012. Only one child per household was surveyed.

\subsection{Variable definition}

We use the term household to refer to members of the household roster of the ELPI survey. Our household transition indicator variables for entry into the household take value 1 if the individual (father or grandparent) is in the household in 2012 but not in 2010. Likewise, the indicator variables for separation take the value of 1 if the individual is present in the household in 2010 but not in 2012.

These variables have some limitations. The grandparent indicator variables only consider if there is at least one grandparent in the household and do not take into account the identity (e.g., paternal grandfather) or number of grandparents, as exploring each of the distinct combinations would result in too small a sample size. We are unaware of the location of the household, but when the father separates from the household he is likely exiting the mother's and child's dwelling, while when the child's household no longer includes grandparents the mother and her child are separating from the grandparent's dwelling. We are unable to account for these distinctions in the analysis and use the term exit and separation interchangeably throughout.

The first outcome variable is receptive vocabulary. The 125-item Test de Vocabulario en Imagenes Peabody (TVIP, Spanish version of the Peabody Picture Vocabulary Test) was administered to children 30 months and older (Dunn et al. 1986). The TVIP was validated in Mexican and Puerto Rican populations and has been used extensively in Latin America (Crookston et al. 2013; Schady et al. 2015). The TVIP was modified for the Chilean context: some target words that were not common in Chile were substituted with more-commonly used words. 
The second outcome variable measures parent-reported child behavior. The Spanish version of the Child Behavioral Checklist (CBCL) was administered to parents of children aged 18 months to 6 years. The CBCL is a validated, reliable, parentcompleted checklist consisting of 99 items assessing a range of problem behaviors relating to socio-emotional well-being (Achenbach and Rescorla 2000). It has been validated in Argentina and Uruguay, two Latin American countries near Chile (Corina 2008; Viola, Garrido, and Rescorla 2011). The CBCL has two major composite scales for Externalizing and Internalizing behaviors. The Externalizing scale is comprised of two subscales (Aggressive Behavior and Attention Problems), and the Internalizing scale has four subscales (Emotionally Reactive, Anxious/Depressed, Somatic Symptoms, and Withdrawn). We present results based on the total score because using the scores for the two sub-scales yielded similar results.

Within each year of the survey and using the entire population tested, we normalize the scores of both these tests. As implemented previously (Fernald et al. 2011), we generate means of 100 and standard deviations of 15 for children within twomonth age windows but do not normalize separately by sex; we include sex as a control variable. In order to make sure that the TVIP and the CBCL can be interpreted in a parallel manner, we adjust the CBCL behavioral scale (maintaining the same mean and standard deviation) so that, for both scales, higher values can be interpreted as having better outcomes (e.g., larger vocabulary, better behavior). Interpretations of changes in outcomes should be considered relative, not absolute.

Our final variable of interest is per capita monthly income. To adjust for a rightskewed distribution we use log of monthly income per capita in US dollars. Twenty percent of families responded with ranges of income, not exact amounts, so for these we impute the amount by using the mean of those who reported exact sums and whose incomes were within the range indicated. If the child's biological father did not live in the household the mother was asked if she received financial support from him: twothirds of mothers not living with the fathers reported that they did. In both years of the survey about 800 mothers did not report "other" income in the income module (the category which would include child support), yet in a different module they indicated they were receiving child support. The 2010 survey does not report the value of the monetary contribution from the biological father, but the 2012 survey does. For households with a discrepancy between income sources, we added the 2012 amount received in child support to 2012 total income. For the 2010 calculation of household income, we applied two-thirds of the 2012 value to 2010 total income if the mother indicated that child support was also received in 2010. We used two-thirds because we found the average value of the 2010 contribution was two-thirds the value of the 2012 contribution among mothers who reported the monetary value of the contribution in both survey years. 
We control for a variety of potential confounders, including child variables (sex, age in months, ever attended preschool, grandmother caregiver), mother variables (age at first birth, employment status, normalized scores of math and vocabulary ability, education level, and indigenous status), and household variables (number of siblings, urban residence, and log per capita income). We also control for father and grandparent presence in the household in 2010 as indicator variables.

\subsection{Attrition and sample size}

About $15 \%$ of children in the 2010 sample were not resurveyed in the 2012 follow-up. Although in 2010 attriters and non-attriters had similar proportions of families with fathers, the non-attriters had a larger percentage of families with grandparents living in the household (39\%) than attriters (33\%). Appendix Table A-1 shows individual testing of means of the 2010 control variables and indicates that two-thirds of these variables differ significantly from each other by attrition status. An F-test of a logit predicting attrition, using the household structure and control variables from 2010, also indicates a statistically significant difference between the two populations, including the household structure variables. We apply inverse probability weights to our analyses to account for this attrition: We multiply the sample weights by the inverse of the probability of being in the sample. This probability is generated by a logit regression (Table A-2). Although some variables significantly predicted attrition the overall fit of the model was low, suggesting that attriters did not predictably differ much from non-attriters. Because of this poor fit the population weights that were re-weighted with the inverse probability weights differ little from the original population weights. Results are robust to using the original population weights.

Almost all young children surveyed lived with their mothers (over 98\%), so we did not include a variable for mother presence and excluded from the analysis those who did not live with their biological mother. We maintained families with stepfathers in the analysis but did not analyze the associations of stepfather presence and child development, since few children had stepfathers $(1.5 \%$ of children in $2010,3 \%$ in 2012).

Although our income analysis includes all children with data in both years, the age ranges are distinct for each assessment (18 months and older for the TVIP; 18 months to 6 years for $\mathrm{CBCL}$ ). We perform our analysis on three samples defined by the availability of each outcome separately (vocabulary $\mathrm{N}=5,170$, behavior $\mathrm{N}=6,330$, and income $\mathrm{N}=10,813)$. An additional sample of children with data on every outcome variable $(\mathrm{N}=3,503)$ we refer to as the 'comparable sample.' This sample allows for comparison of results across the outcome variables, since the population is the same. 


\subsection{Sample description}

In 2010 over one-third of children lived with at least one grandparent and almost onethird did not have their biological father living in their household; between 2010 and 2012, 21\% experienced a household transition involving fathers and/or grandparents. Specifically, 20\% of children with a grandparent in the household in 2010 no longer lived with their grandparents by $2012.9 \%$ of children with a father in the household in 2010 no longer had the father in the household by $2012.13 \%$ of children without a father in the household experienced their biological fathers joining the household. A transition table shows the percentages of children experiencing the different types of household transition (Table 1). The probability of children with cohabitating fathers experiencing father separation (9\%) is lower than the probability of children without cohabitating fathers experiencing biological father entrance into the household (13\%).

Table 1: Percentages of children in different household structures of fathers and grandparents by survey year

\begin{tabular}{|c|c|c|c|c|c|c|}
\hline & & \multicolumn{5}{|c|}{2012 Household structure } \\
\hline & & $\begin{array}{l}\text { Neither } \\
\text { grandparent } \\
\text { nor father }\end{array}$ & $\begin{array}{l}\text { Both grandparent } \\
\text { and father }\end{array}$ & $\begin{array}{l}\text { Grandparent } \\
\text { only }\end{array}$ & Father only & Total \\
\hline \multirow{5}{*}{$\begin{array}{l}2010 \\
\text { Household } \\
\text { structure }\end{array}$} & $\begin{array}{l}\text { Neither grandparent } \\
\text { nor father }\end{array}$ & $6.70 \%$ & $0.10 \%$ & $0.70 \%$ & $1.50 \%$ & $9.10 \%$ \\
\hline & $\begin{array}{l}\text { Both grandparent } \\
\text { and father }\end{array}$ & $0.40 \%$ & $8.70 \%$ & $1.90 \%$ & $4.30 \%$ & $15.30 \%$ \\
\hline & Grandparent only & $2.20 \%$ & $1.60 \%$ & $17.00 \%$ & $1.70 \%$ & $22.50 \%$ \\
\hline & Father only & $3.70 \%$ & $1.50 \%$ & $1.00 \%$ & $46.90 \%$ & $53.10 \%$ \\
\hline & Total & $13.10 \%$ & $11.90 \%$ & $20.60 \%$ & $54.30 \%$ & $100 \%$ \\
\hline & $N=12,898$ & & & & & \\
\hline
\end{tabular}

Note: Father refers to biological father. Grandparent refers to any grandparent. Mothers are present in $98 \%$ of households. 
Reynolds et al:: Family structure and child development in Chile

Table 2: $\quad$ Summary statistics of household structure

\begin{tabular}{|c|c|c|c|c|c|}
\hline & Sample defined by availability of outcome: & Vocabulary & Behavior & Income & All $^{*}$ \\
\hline \multirow{4}{*}{$\begin{array}{l}\text { Household } \\
\text { structure } \\
\text { in } 2010\end{array}$} & Father in household & $70 \%$ & $69 \%$ & $69 \%$ & $70 \%$ \\
\hline & Grandparent(s) in household & $35 \%$ & $37 \%$ & $38 \%$ & $35 \%$ \\
\hline & Father in household X grandparent(s) in household & $14 \%$ & $14 \%$ & $15 \%$ & $13 \%$ \\
\hline & Mother only in household 2010 & $9 \%$ & $8 \%$ & $8 \%$ & $8 \%$ \\
\hline \multirow{6}{*}{$\begin{array}{l}\text { Household } \\
\text { transitions } \\
\text { from } \\
2010-2012\end{array}$} & Separate from grandparent(s) & $8 \%$ & $8 \%$ & $8 \%$ & $8 \%$ \\
\hline & Join father & $4 \%$ & $5 \%$ & $5 \%$ & $4 \%$ \\
\hline & Separate from grandparent $X$ join father & $1 \%$ & $2 \%$ & $2 \%$ & $1 \%$ \\
\hline & Separate from father & $6 \%$ & $6 \%$ & $6 \%$ & $6 \%$ \\
\hline & No transition & $84 \%$ & $83 \%$ & $82 \%$ & $84 \%$ \\
\hline & $\mathrm{N}$ & 5,170 & 6,330 & 10,813 & 3,503 \\
\hline
\end{tabular}

Note: * Observations have values for all outcome variables; referred to as 'comparable sample' in the text.

Source: 2010-2012 ELPI; Sample defined by children with complete values on all control variables; see Table 3 for controls and outcomes.

\section{Table 3: $\quad$ Summary statistics}

\begin{tabular}{|c|c|c|c|c|c|c|c|c|c|}
\hline & \multirow{2}{*}{$\begin{array}{l}\text { Sample defined by } \\
\text { availability of } \\
\text { Variable }\end{array}$} & \multicolumn{2}{|c|}{$\begin{array}{l}\text { Vocabulary } \\
\text { outcome } \\
\qquad N=5,170\end{array}$} & \multicolumn{2}{|c|}{ 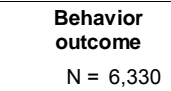 } & \multicolumn{2}{|c|}{$\begin{array}{l}\text { Income } \\
\text { outcome } \\
N=10,813\end{array}$} & \multicolumn{2}{|c|}{$\begin{array}{c}\text { All } \\
\text { outcomes* }^{*} \\
\mathrm{~N}=3,503\end{array}$} \\
\hline & & mean & sd & mean & sd & mean & sd & mean & sd \\
\hline \multirow{8}{*}{$\begin{array}{l}\text { Child } \\
\text { variables }\end{array}$} & Vocabulary score (TVIP 2010) & 100.06 & 14.93 & 100.06 & 15.09 & 99.99 & 14.90 & 100.12 & 15.09 \\
\hline & Vocabulary score (TVIP 2012) & 100.35 & 14.88 & 100.13 & 14.90 & 100.11 & 14.93 & 100.22 & 14.95 \\
\hline & Behavior score (CBCL 2010) & 99.55 & 14.94 & 99.53 & 14.98 & 99.73 & 14.93 & 99.43 & 14.99 \\
\hline & Behavior score (CBCL 2012) & 99.97 & 14.78 & 99.97 & 14.86 & 100.02 & 14.92 & 99.96 & 14.79 \\
\hline & Female & 0.50 & 0.50 & 0.50 & 0.50 & 0.49 & 0.50 & 0.50 & 0.50 \\
\hline & Age in months (2010) & 41.08 & 6.88 & 31.52 & 8.16 & 30.44 & 12.80 & 37.52 & 4.85 \\
\hline & $\begin{array}{l}\text { Ever attended preschool } \\
(2010)\end{array}$ & 0.65 & 0.48 & 0.45 & 0.50 & 0.45 & 0.50 & 0.56 & 0.50 \\
\hline & Grandmother caregiver (2010) & 0.17 & 0.37 & 0.17 & 0.37 & 0.16 & 0.37 & 0.17 & 0.38 \\
\hline \multirow{7}{*}{$\begin{array}{l}\text { Mother } \\
\text { variables }\end{array}$} & Mother's age at first birth & 22.59 & 5.25 & 22.40 & 5.26 & 22.40 & 5.23 & 22.55 & 5.26 \\
\hline & Mother employed (2010) & 0.45 & 0.50 & 0.42 & 0.49 & 0.42 & 0.49 & 0.44 & 0.50 \\
\hline & $\begin{array}{l}\text { Mother's math ability score } \\
\text { (WAIS) }\end{array}$ & 99.60 & 14.72 & 99.71 & 14.76 & 99.73 & 14.96 & 99.75 & 14.90 \\
\hline & $\begin{array}{l}\text { Mother's vocabulary ability } \\
\text { score (WAIS) }\end{array}$ & 99.71 & 14.91 & 99.63 & 14.86 & 99.66 & 14.91 & 99.72 & 14.88 \\
\hline & $\begin{array}{l}\text { Primary education only } \\
\text { completed }\end{array}$ & 0.19 & 0.39 & 0.18 & 0.39 & 0.18 & 0.39 & 0.19 & 0.39 \\
\hline & $\begin{array}{l}\text { Secondary education but no } \\
\text { tertiary }\end{array}$ & 0.59 & 0.49 & 0.60 & 0.49 & 0.60 & 0.49 & 0.60 & 0.49 \\
\hline & Indigenous & 0.08 & 0.28 & 0.08 & 0.28 & 0.08 & 0.28 & 0.08 & 0.27 \\
\hline \multirow{4}{*}{$\begin{array}{l}\text { Household } \\
\text { variables }\end{array}$} & Number of siblings & 1.01 & 1.00 & 0.95 & 0.99 & 0.94 & 1.00 & 0.98 & 1.00 \\
\hline & Urban & 0.89 & 0.32 & 0.89 & 0.32 & 0.89 & 0.31 & 0.89 & 0.31 \\
\hline & Log per capita income (2010) & 4.92 & 0.84 & 4.92 & 0.84 & 4.93 & 0.85 & 4.92 & 0.84 \\
\hline & Log per capita income (2012) & 5.15 & 0.78 & 5.16 & 0.78 & 5.17 & 0.79 & 5.16 & 0.77 \\
\hline
\end{tabular}

Note: *Referred to as the 'comparable sample' in the text. Variables without standard deviation are dichotomous. Vocabulary is standardized (mean 0; sd 15) score on the Spanish version of the Peabody Picture Vocabulary Test. Behavior is standardized (mean 0 ; sd 15) score on the Child Behavior Checklist. Income is log per capita income in Chilean pesos/500 1US\$. Source: 2010-2012 ELPI; Sample defined by children with complete controls and test score/income data. 
$79 \%$ of children who had grandparents in the home in either survey year lived with maternal grandparents. Families were more likely to have grandmothers in the household than grandfathers: $40 \%$ of households with grandmothers did not have grandfathers, but only about $10 \%$ of households with grandfathers did not have grandmothers in either survey year.

The pattern of household transitions suggests that mothers tend to move away from their parents and form independent households with biological fathers. Over $50 \%$ of first-time mothers lived with the children's grandparents in 2010, suggesting that many women do not leave their parents' home before the first child is born; this portion drops for subsequent children (Figure 1). Additionally, older mothers are less likely than younger mothers to live with their children's grandparents and more likely than younger mothers to live only with the children's father (Figure 2). The fraction of mothers living with their own parents has stayed relatively constant over time; the Appendix includes additional details about historical data.

\section{Figure 1: Percentages of mothers in different household arrangements by} number of children

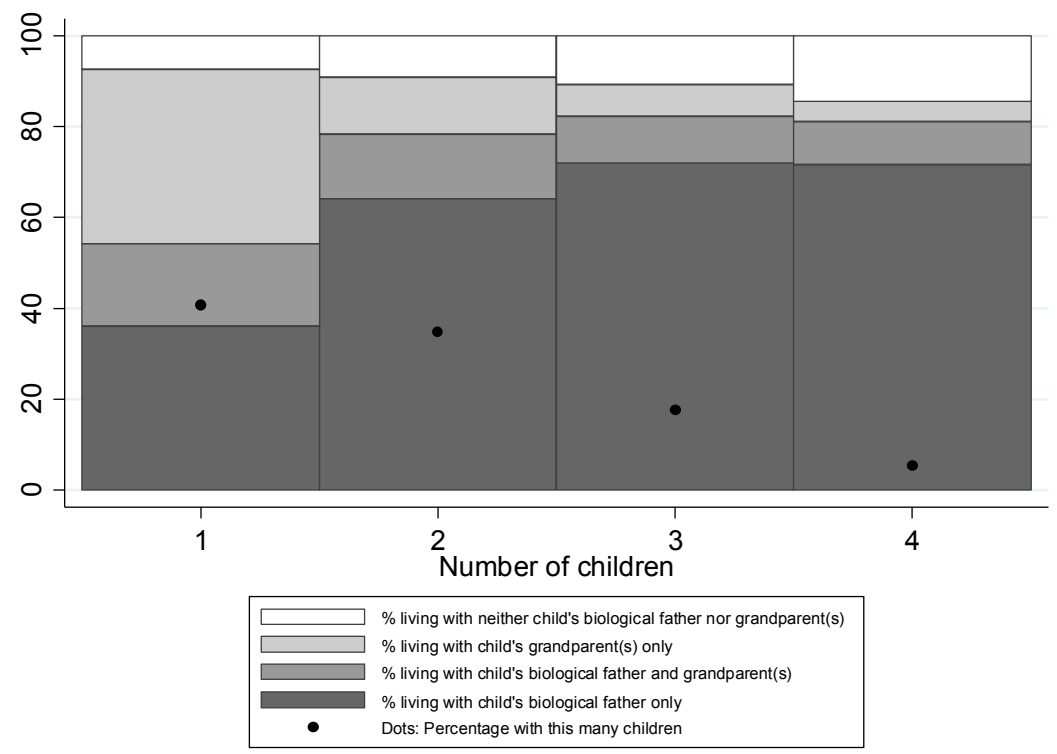

Source: ELPI 2010. 
Figure 2: Percentages of mothers in different household arrangements by age

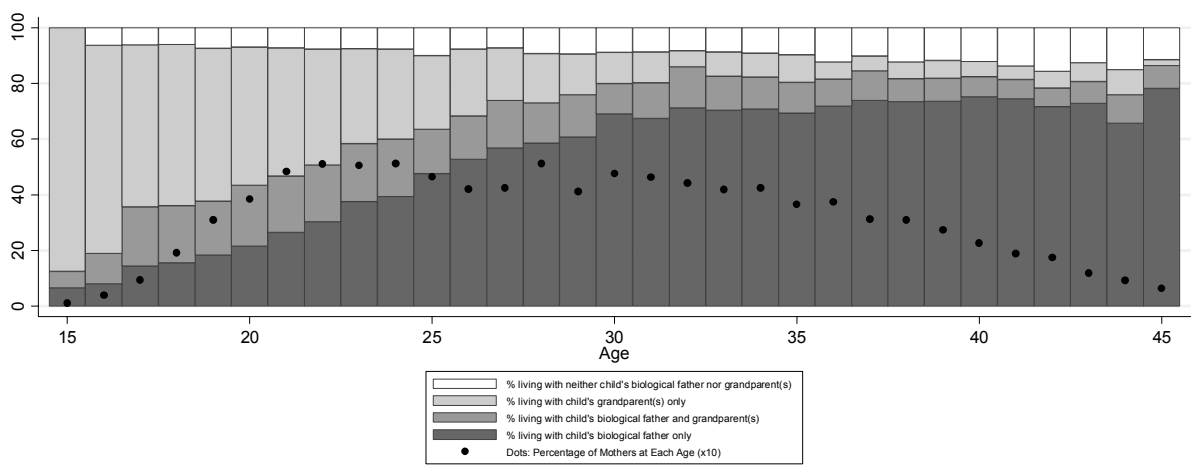

Source: ELPI 2010.

Children in our final sample were 7-58 months old in 2010 and 33-83 months in 2012. Children in the TVIP sample were 30-58 months and 52-83 months in 2010 and 2012 respectively. Children in the CBCL sample were 18-50 months and 39-71 months in 2010 and 2012 respectively. Children in the comparable sample were 30-50 months and 52-71 months in 2010 and 2012 respectively. Summary statistics for the outcome variables and additional covariates are presented in Tables 2 and 3. Between 2010 and 2012, two-thirds of the control variables differed statistically between families with a stable household structure and families that experienced a transition (Table A-3).

\section{Main analysis}

\subsection{Empirical specification}

We apply two estimation strategies to the longitudinal data to evaluate the association between household transitions and child development outcomes. If our models are correct, we can assign causality to the relationship. While we use causal terminology such as 'bias' in the empirical discussion, particularly since longitudinal analysis is more plausibly causal than a cross-sectional approach, we conservatively use the word 'association' to discuss the results.

The lagged-dependent-variable model implies that growth in child development in the current period is dependent on past levels as well as on fixed variables such as mother's intelligence. The estimation strategy is a standard OLS model with additional controls for prior values of the outcome variables: 


$$
\mathrm{Y}^{\mathrm{j}}{ }_{2012}=\mathrm{a}_{0}+\mathrm{a}_{1} \mathrm{G}^{-}+\mathrm{a}_{2} \mathrm{~F}^{+}+\mathrm{a}_{3} \mathrm{G}^{-} \times \mathrm{F}^{+}+\mathrm{a}_{4} \mathrm{~F}^{-}+\mathrm{a}_{5} \mathrm{X}_{2010}+\mathrm{a}_{6} \mathrm{Y}_{2010}+\mathrm{e}
$$

$\mathrm{Y}$ is the $\mathrm{j}^{\text {th }}$ outcome variable (vocabulary, behavior, or income per capita) in 2012. $\mathrm{F}$ and $\mathrm{G}$ refer to biological father and grandparent transition indicator variables, with the superscript minus or plus indicating separation from or entry into the household, respectively. The omitted category is 'no transition.' We exclude 3\% of households with transitions in which grandparents join the household or in which there is separation from both grandparent(s) and father. There are sufficient observations to allow including an interaction term indicating the grandparent separating and the father joining. $\mathrm{X}_{2010}$ are mother, child, and household characteristics, and we also control for 2010 values of the outcome variables $\left(\mathrm{Y}_{2010}\right)$. In some specifications (larger samples), however, we only include the $j^{\text {th }}$ outcome variable on the right hand side. The error term is represented by e.

Since endogeneity of the lagged term is a concern with the lagged dependent variable model, we include first differences as a robustness check. This model examines changes in child development and assumes these changes are only based on timevarying factors. In the first difference estimation strategy (equivalent to child fixedeffects) we do not include controls because most of our covariates are time invariant, and those that were not - preschool attendance, number of siblings, and per capita income - are endogenous and dependent on household structures. Age varies with time, but our outcome variables are normalized by age and the variation is about the same for everyone: the two years between surveys.

$$
\Delta \mathrm{Y}=\alpha_{0}+\alpha_{1} \mathrm{G}^{-}+\alpha_{2} \mathrm{~F}^{+}+\alpha_{3} \mathrm{G}^{-} \times \mathrm{F}^{+}+\alpha_{4} \mathrm{~F}^{-}+\varepsilon
$$

To directly compare the first difference model to the lagged outcome variable model, the first-differences model changes the outcome to $\Delta \mathrm{Y}$ and removes $\mathrm{Y}_{2010}+$ $\mathrm{X}_{2010}$ from the right side, in effect imposing the restriction that $\mathrm{a}_{6}$ be equal to 1 . $^{7}$ This introduces the concern that the first-difference estimation will be biased should the restriction be unrealistic. Yet the lagged-dependent-variable estimation has its own concerns, since it does not control for unobserved, time-invariant factors. Fortunately, the lagged-dependent-variable and first-differences estimates bound the true value if the true model happens to be a combination of both types of model (and is not correlated with unobserved time-variant factors) (Angrist and Pischke 2008). We do not attempt to estimate this combined model because conditions for consistent estimation are much more demanding than for either alone (Angrist and Pischke 2008); instead we compare the two methods for robustness.

${ }^{7}$ Empirical tests of $\mathrm{a}_{6}=1$ fail, suggesting that the more complex model described in this paragraph is more likely. 
We apply the two approaches to each sample: the larger samples (one each for vocabulary, behavior, and income) and the comparable sample, which restricts the sample based on the availability of the other outcome variables. We delete observations with missing values of any variable, but also apply multiple imputation as a robustness check and get similar results (available upon request).

For each outcome we present four specifications: (1) first differences using the sample specific to the outcome variable, (2) and (3) lagged dependent variable with and without controls using the sample specific to the outcome variable, and (4) lagged dependent variable with controls using the comparable sample. In the comparable sample specifications we also include the other child development test's lagged value as a control to gain precision. We apply the sample weights multiplied by the inverse probability weights generated to correct for attrition in all regressions.

\subsection{Results}

Both first-differences and lagged-dependent-variable estimations provide similar estimates: We find children whose mothers separate from their parents' household score more than $10 \%$ of a standard deviation lower on vocabulary skills than those who experience no disruptions in father or grandparent presence (Table 4). Using the smaller comparable sample, the magnitude is a third smaller and not statistically significant, though this estimate is still within a standard error of those of the other models (Model 4). We find no statistically significant changes in vocabulary or behavior scores associated with father transitions. However, income per capita increases by around $20 \%$ when fathers join households or grandparents separate, and there is a reduction, of smaller magnitude (15\%), in per capita income when fathers exit the household. 
Table 4: $\quad$ First differences and lagged outcome variable estimations

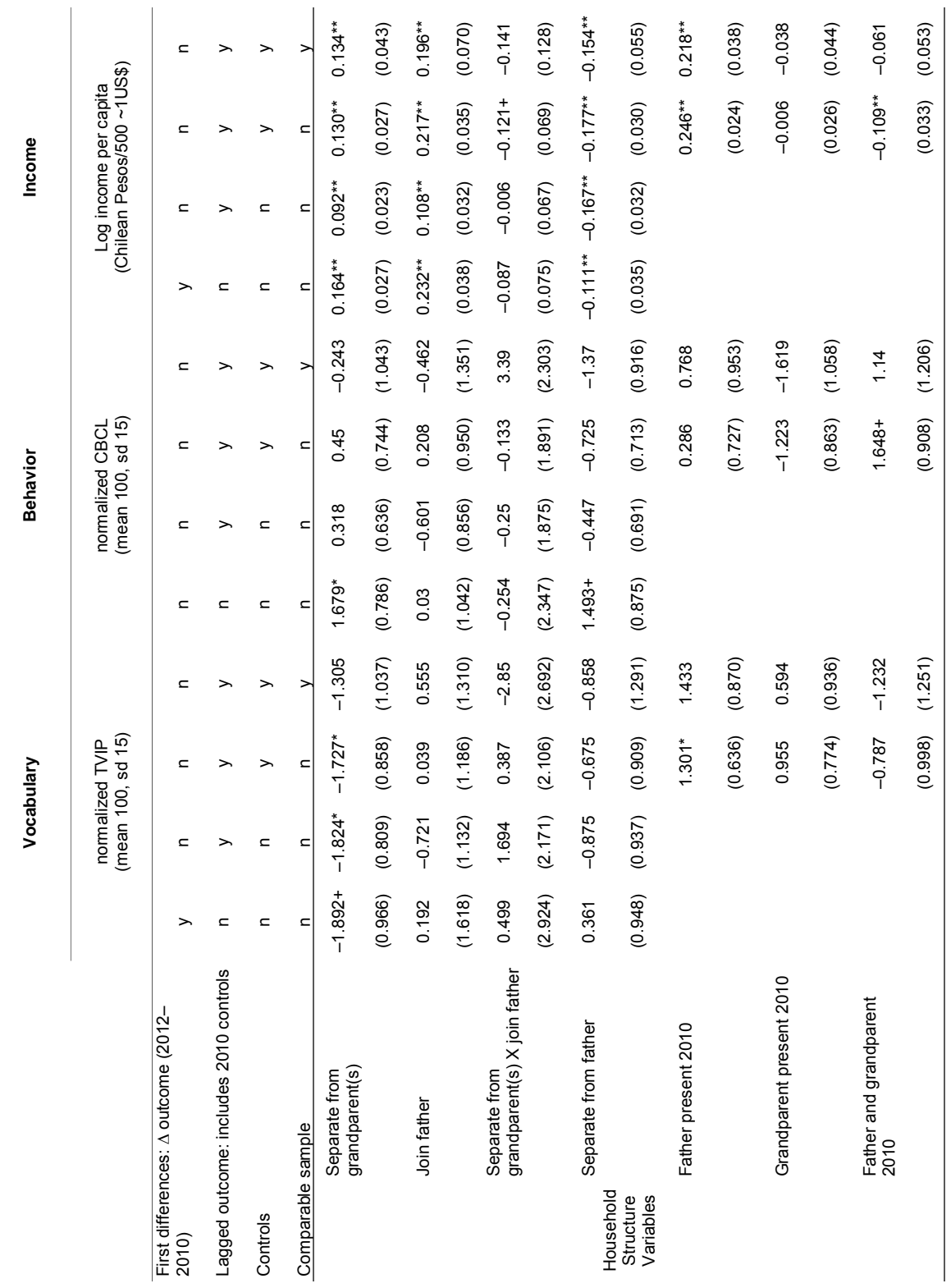


Table 4: (Continued)

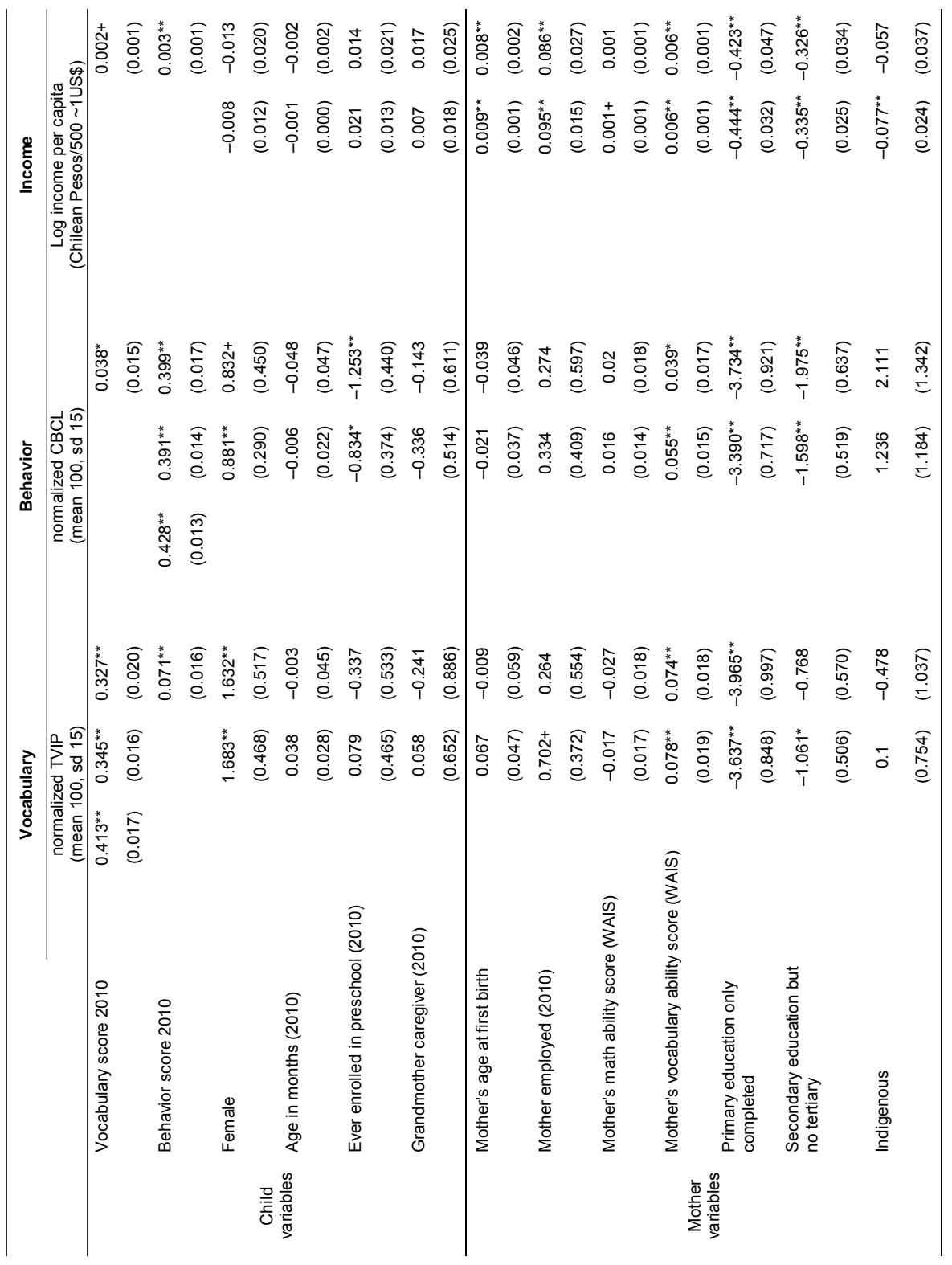


Table 4: (Continued)

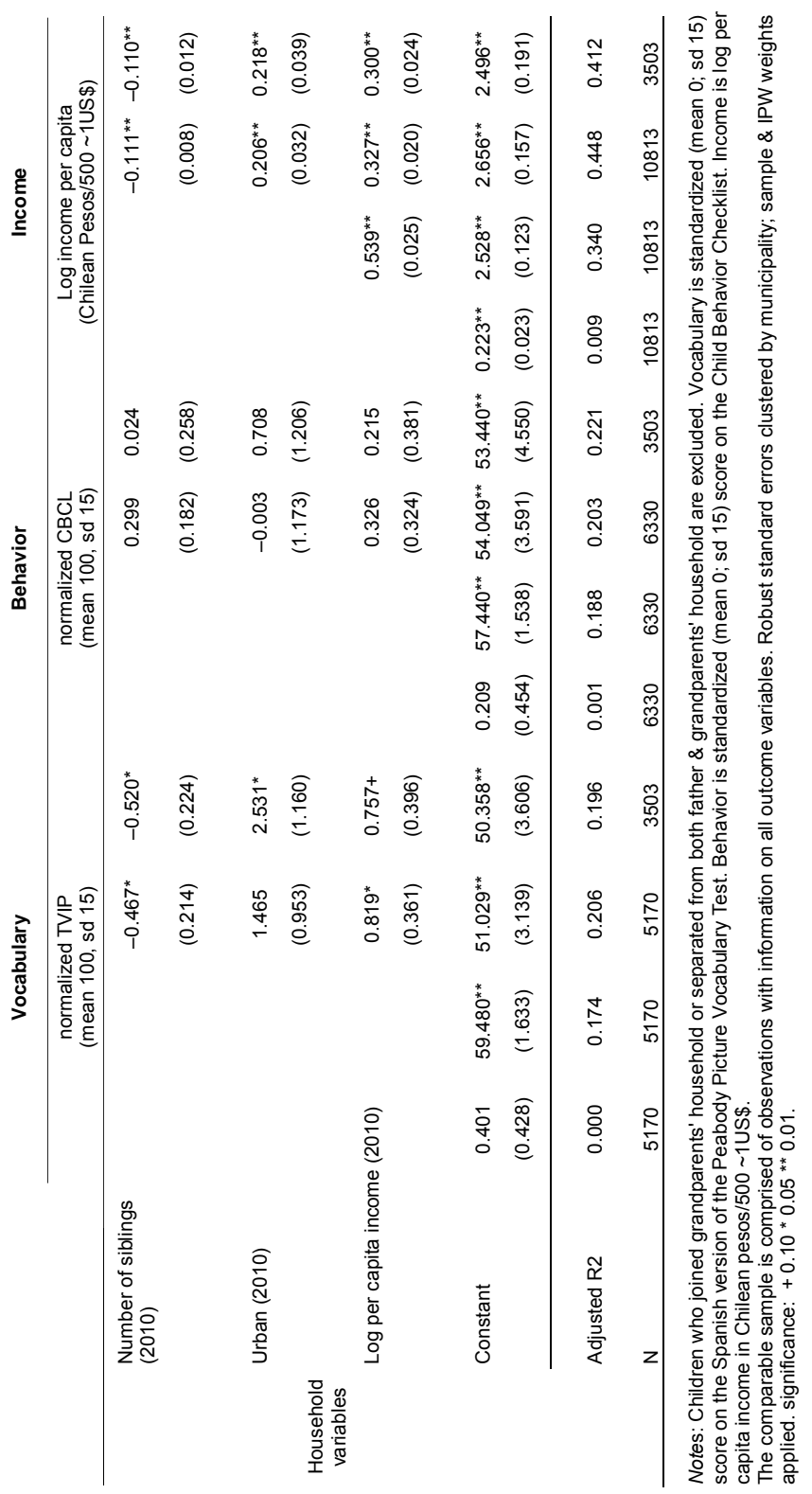




\section{Supporting analyses}

\subsection{Robustness checks for identity}

First, we pool all the transitions and test the associations for any transition. We find some evidence of transitions being associated with a small increase in income per capita, but less robust evidence of reductions in normalized vocabulary score and improvements in behavior (Table 5). These weaker results, due to not taking into account the family member's identity, suggest that the transition itself is not the mechanism behind the main findings but the identity of the transitioner is important.

We then test the associations between household transitions and child development by considering subsamples. It is possible that groups of children living with grandparents, with fathers, or without fathers have different associations between the outcome and the control variables. For example, the association with mothers' education may be distinct depending on whether other earners are in the household. Thus we stratify analysis by these groups. Specifically, we examine grandparent separation only among children who lived with a grandparent in 2010; we examine father separation only among children who lived with a father in 2010; and we examine father entrance only among children who did not live with a father in 2010 . The results support the main findings (Table 5). We find changes in the scores of subsets of the sample (e.g., children who lived with grandparent(s) in 2010, children who lived with fathers in 2010, and children who did not live with fathers in 2010), with one exception: Children who separated from grandparents exhibited a decline in vocabulary scores compared to those who remained in the same household as their grandparents, and these magnitudes are similar to those found when using the full sample. Unlike Model 4 in Table 4, Model 4 in Table 5 has as similar magnitude for the estimated transition effect as the other models, though the smaller sample size yields less statistical significance. Results for income are also similar to the main findings. 
Table 5: First differences and lagged outcome variable estimations by subsample

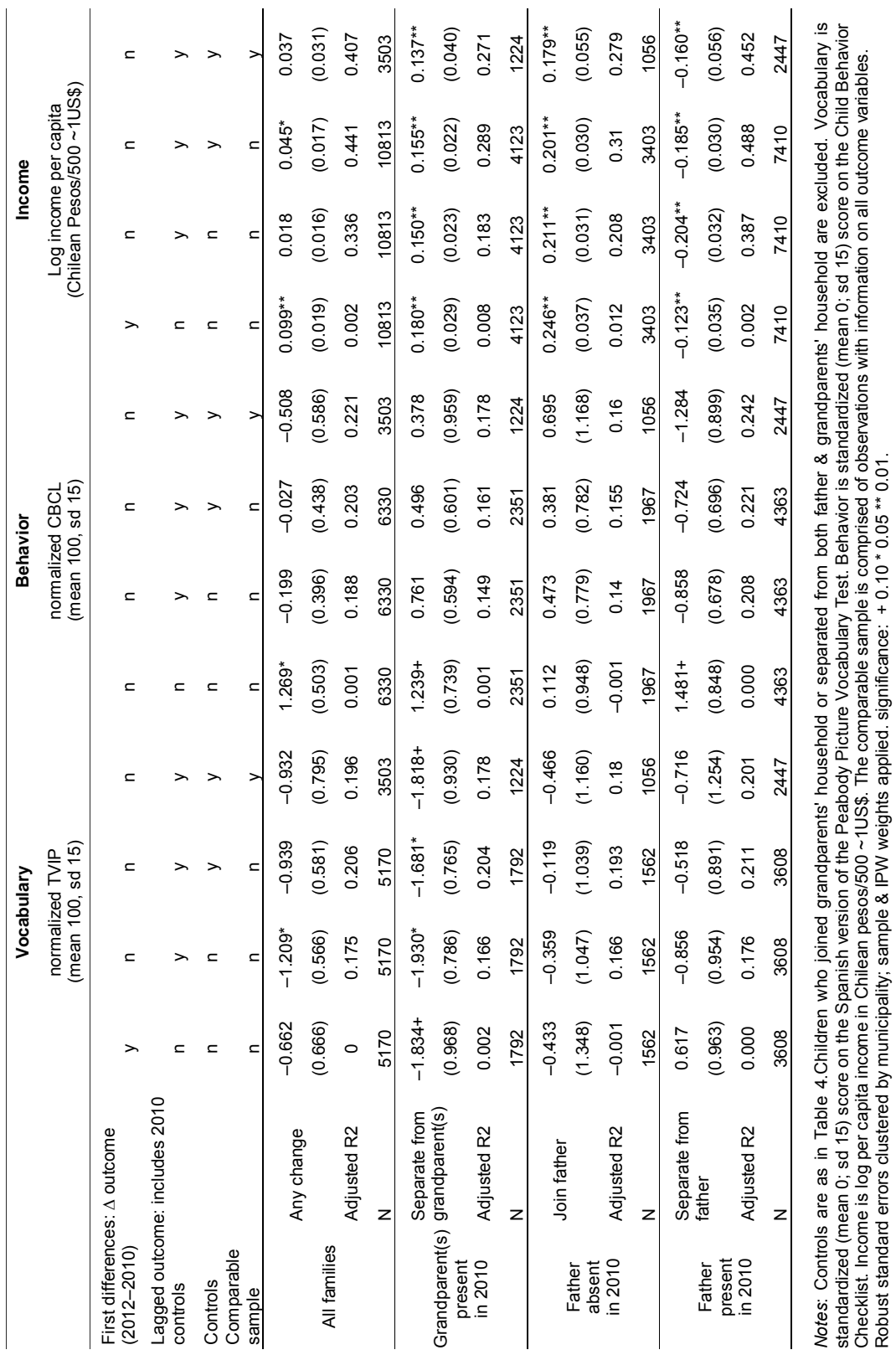




\subsection{Does income explain the association between grandparent separation and reduced vocabulary scores?}

Since income is also associated with grandparent separation, we test if income per capita explains the association between grandparent separation and child vocabulary; reduced income could be a reason why children's normalized vocabulary scores are lower when grandparents exit the household. Because the association between household transitions and behavior is not statistically significant we do not explore income in this context. For the vocabulary outcome, we include change in log income per capita in the first-differences regression and include log income per capita in 2012 in the lagged-dependent-variable regressions; $2010 \mathrm{log}$ income per capita is already included as a control variable. These analyses examine if the inclusion of these income variables weakens the original associations (Baron and Kenny 1986). We use the Stata command medeff (Hicks and Tingley 2011), which applies procedures developed by Imai, Keele, and Tingley (2010) to estimate the potential indirect effect of grandparent separation via income on child vocabulary, should the association indeed be causal. The bootstrapped estimates use 1,000 repetitions and range from 0-0.19 standard deviations. Controlling for change in income, the coefficient estimate on grandparent separation changed by no more than 0.2 ( $15 \%$ of the main effect or $1.3 \%$ of a standard deviation) and the significance levels remained the same (full regression available upon request).

Though one might expect changes in income to be driven by changes in mothers' employment, there is little change in female employment between rounds (Table A-4). The highest increase in the rate of mother employment, $14 \%$, is found in families where the father separates. We also note that these families have the highest magnitude of change in grandparent caregiving, with $10 \%$ of families adding a grandparent as primary caregiver between rounds. By contrast, only $5 \%$ of families where the grandparent exits replace the grandparent as primary caregiver with someone else. Increases in preschool attendance are similar among all family types, whether experiencing a household transition or not, although families where the father exits had a notably higher level of preschool enrollment in 2010.

\section{Discussion}

Using a large, nationally representative survey from Chile, we compare household transitions of fathers and grandparents into and out of households, and the longitudinal associations of these household transitions with child development outcomes. Our findings highlight the importance of grandparents in the lives of their grandchildren's development, particularly since one-third of young Chilean children live with 
grandparents and Chilean children frequently experience grandparent transitions. Grandparent separation is associated with lower child vocabulary development and greater household income per capita. By contrast, father transitions are not associated with child development outcomes, only with household income.

Though our literature review suggests that any type of household transition could be associated with changes in vocabulary and behavior, we find father transitions are not associated with vocabulary and behavioral child outcomes between ages 3 and 7 years. Grandparent presence, however, is positively associated with vocabulary: We find that child vocabulary scores are $10 \%$ higher in households where a grandparent remained living with their grandchildren rather than separated. We also find that changes in household income do not explain much of this association: Household income per capita increases upon grandparent separation, suggesting that grandparents' average income per capita is lower than that of mothers and fathers. If income influences cognition we would expect vocabulary scores to increase when grandparents leave, but we find the opposite. Yet, though a potential financial liability, the contribution of grandparents to child development appears valuable in the vocabulary realm.

Per capita income may increase for a variety of reasons when the grandparents separate from the household. As mentioned above, they may not be earning income and therefore are a liability for their child to support. On the other hand, the increase may be purely functional: even if they provide income to the family, if two grandparents separate the remaining income is divided by even fewer people. Finally, the separation may be spearheaded by mothers' employment, in which case income increases, but not due to the grandparents. However our descriptive statistics suggests mothers' employment fluctuates relatively little in the face of household transitions (Table A-4). We refrain from drawing conclusions regarding whether the increase in income offsets the loss in vocabulary score because we did not assess the many other realms of child development and welfare. A tentative policy suggestion is for policymakers and educators interested in supporting children's vocabulary to target families experiencing these transitions, although more data and analyses are needed to understand the mechanisms before designing interventions.

Contextualizing our findings within the literature suggests that Chilean and US contexts are more similar regarding grandparenthood than fatherhood. Previous work from the United States on grandparents aligns with our findings on vocabulary scores. For example, Aquilino (1996) and Deleire and Kalil (2002) study US families and find that grandparent presence is correlated with improved educational outcomes, though their findings concentrate on families with single mothers. Other work on single mothers in the United States suggests that grandparent presence supports cognitive stimulation in the home (Dunifon and Kowaleski-Jones 2007). Our study adds to this 
literature as we extend longitudinal analysis of grandparent influence beyond single mothers and include a sample of children in early childhood. Only the Dunifon and Kowaleski-Jones study includes some elementary-age school children; the other studies focus on adolescent or adult outcomes.

In comparison to non-US studies, our work complements the findings of Schmeer, who examines child anemia and family structure in Mexico in a context of family transitions arising from migration (2013). She finds father and grandparent transitions not to have significant association with child anemia, but the rates of transition for her sample were between $2 \%$ and $5 \%$ over a three-year period, lower than in our Chilean sample over a two-year period. She finds children with a stable maternal-grandparent presence have lower anemia, suggesting that grandparents can support child nutrition. In line with our general findings on grandparents, studies on pensions from Brazil (Ponczek 2011) and South Africa (Duflo 2003) have also found that grandparents can support early child development. We refrain from suggesting that our findings for grandparents are valid for other cultures, though other Latin American nations with high rates of teen and early pregnancy and where intergenerational coresidence is common would be most likely to yield similar results. Yet though Peru and Colombia have similar rates of adolescent pregnancy to Chile (United Nations, Department of Economic and Social Affairs, Population Division 2015), Chile is culturally more similar to the wealthier nations of Argentina and Uruguay. Thus it is possible that our Chilean findings on grandparents are unique to Chile; more research is needed to determine if these trends are consistent internationally.

We find father transitions in Chile to be consistent with data from Europe and the United States: The probability of children of married parents experiencing divorce is lower than the probability of children of single mothers partnering (Andersson 2004). Similar to US studies (Amato 2010; McLanahan, Tach, and Schneider 2013; Page and Stevens 2004; Thomson, Hanson, and McLanahan 1994), we find changes in household per capita income associated with father transitions. The magnitude of the drop in per capita income when fathers exit the household is smaller than the increase in per capita income associated with fathers entering the household. This discrepancy in magnitude suggests that mothers whose partners leave the household partially make up income losses through employment, social subsidies, or child support, which are all included in our total income measure. In contrast to many US findings (Amato and Gilbreth 1999; McLanahan, Tach, and Schneider 2013), we do not find father transitions to be associated with the assessed child development outcomes, though Contreras and González (2015) use the 2010 ELPI cross-sectional data and find that children living with both of their parents have higher vocabulary scores than children living with only their mother. This difference in findings may be because their cross-sectional study 
focuses on differences between children rather than differences over time for the same children.

We do not find any longitudinal associations between household transitions and children's behavior. This result is surprising because poor socio-emotional adjustment is one of the strongest findings in reviews of father absence, including laggeddependent-variable studies, with effects potentially "more pronounced if father absence occurs during early childhood than during middle childhood" (McLanahan, Tach, and Schneider 2013). Many of the studies reviewed consider internal and externalizing behaviors, analogous to those measured by the CBCL in our study; however, none are from Latin America. On the other hand, a systematic review of literature on depressive symptoms (including internalizing behavior) and divorce finds little evidence of age at parents' divorce being important, though the age of the children may matter: males aged 10 and females aged 15 are most at risk of depressive symptoms (Di Manno, Macdonald, and Knight 2015). Reduced engagement with the father may explain these results, with the sexes differing in sensitivity to father absence at different ages.

The lack of an association between father transitions and child vocabulary scores combined with the association between grandparent separation and child vocabulary scores suggests two possible explanations, which we are unable to test with this data. Although the understanding of fatherhood in Chile has evolved to include the ideals of confidant, friend, tutor, and nurturer in addition to protector and provider, Chilean fathers largely continue to be employed full-time and may be less available for children, even when living in the household (Rebolledo 2008; Valdés 2009). As such, fathers outside the household may maintain similar levels of interaction as fathers inside the household. Grandparents, on the other hand, may be unable to maintain the same levels of involvement when non-coresident. That involvement might include supporting the mother in household chores as well as caring for the children. Thus, if Chile has strongly delineated gender roles for household chores, father presence may not allow mothers to spend more time with their children to the same degree as grandparent presence. To understand which mechanisms are driving the results, more data is needed on interactions between non-nuclear family members, children, and mothers, and between non-coresident family members, children, and mothers. Information on the amount of time spent in different types of interaction can be helpful (educational, play, household, etc.), as well as the quality of the interaction (listening to children's problems, providing emotional support, discipline).

The young ages of the children in our sample are a strength of the study, given that only a small proportion of the literature considers these family impacts on young children; but it is also a limitation, as the impact of grandparents and fathers may change with children's age. For example, fathers' parenting role may be moderated by child age, with different interactions with pre-primary children and with older children 
and adolescents (Cabrera et al. 2007). With older children, fathers can participate in activities such as sports, video games, and camping, while interactions with younger children require more caretaking, which is often culturally considered 'maternal.' The age of the child may be more important than the age at which the transition took place, perhaps with father absence felt more acutely in later childhood and adolescence, the ages at which fathers are more involved with children. Follow-up research on these children will be important to determine if these mechanisms hold in the Chilean context.

Several study limitations should be noted. First, although the lagged-dependentvariable regression models included extensive controls and accounted for differences in baseline values of the outcome variables, we cannot fully account for all unobserved factors. The first-difference models do control for all fixed unobserved variables, but not for time-varying unobserved variables. Second, due to a lack of international or national standards for the PPVT and CBCL, the child development outcome variables are not normalized to an absolute scale but instead are relative to their peers in each survey year; thus results should be interpreted as relative changes rather than absolute changes. Third, while we adjusted for attrition using inverse probability weights, this method is not fully corrective if the attrition was related to unobserved variables. Finally, our transition variables are somewhat limited. We do not know how long the fathers and grandparents lived with the child prior to the survey, nor do we know when during the two-year window between survey rounds the transition occurred. We only examined grandparent separation; we do not examine grandparents joining households since this transition is not part of the pattern that emerges in our descriptive analysis. Even in the grandparent separation variable we do not distinguish grandmothers from grandfathers or maternal from paternal grandparents. We note that when grandparents are living in the home the most likely scenario is the presence of both maternal grandparents, followed by that of maternal grandmothers. We do not consider the case of one grandparent leaving the household but another remaining.

This study leaves us with additional research questions that emphasize the need for additional data on family members outside the home. Information on the exact timing of changes in biological fathers' and grandparents' presence in the household could allow examination of the permanence of the associations we explore. Information as to whether the child changes residence and distance from the original home could allow us to test if the additional stress of moving location is more or less associated with changes in household composition. The degree of contact or type of interaction that fathers and grandparents have - both inside and outside the children's household - could help determine mechanisms by which these family members influence child development. Future work needs to consider potential heterogeneous impacts by sex and age of child, as has been found to matter in the literature on divorce (Anthony, DiPerna, and Amato 
2014). However, the data limitations with respect to lower power for subgroup analyses imply that unless results are strikingly different the confidence intervals for the estimates will overlap, making conclusions in this regard tenuous. Our initial investigations suggested differences by gender, but they are not statistically significant so we do not report them.

In spite of these limitations and topics to be explored in future research, our study results contribute to the body of literature that suggests that non-nuclear family members influence child development, and that these influences do not work through income. Chilean policymakers and NGOs supporting children and families may wish to target mothers who move out of their parents' household and provide them with additional support for their children's cognitive development. In addition, there may be benefits to providing parental coaching for fathers who enter households, to help them better engage with their children. Programs that support children in families with separating parents can become even more effective by expanding to serve families experiencing different types of household transition, particularly since young Chilean children experience grandparent separation more frequently than father separation. More generally, directly involving grandparents may help family programs that support early childhood become more effective.

\section{Acknowledgments}

This work was supported by the Eunice Kennedy Shriver National Institute of Child Health and Human Development (NICHD K99HD08875 and R01HD065436) and Grand Challenges Canada (Grant 0072-03). 


\section{References}

Achenbach, T.M. and Rescorla, L.A. (2000). Manual for the ASEBA preschool forms and profiles. Burlington: University of Vermont, Research Center for Children, Youth, and Families.

Amato, P.R. (2010). Research on divorce: Continuing trends and new developments. Journal of Marriage and Family 72(3): 650-666. doi:10.1111/j.1741-3737. 2010.00723.x.

Amato, P.R. and Gilbreth, J.G. (1999). Nonresident fathers and children's well-being: A meta-analysis. Journal of Marriage and Family 61(3): 557-573. doi:10.2307/ 353560 .

Andersson, G. (2004). Children's experience of family disruption and family formation: Evidence from 16 FFS countries. Vienna Yearbook of Population Research 2004: 313-332.

Angrist, J.D. and Pischke, J.-S. (2008). Mostly harmless econometrics: An empiricist's companion. Princeton: Princeton University Press.

Anthony, C.J., DiPerna, J.C., and Amato, P.R. (2014). Divorce, approaches to learning, and children's academic achievement: A longitudinal analysis of mediated and moderated effects. Journal of School Psychology 52(3): 249-261. doi:10.1016/ j.jsp.2014.03.003.

Aquilino, W.S. (1996). The life course of children born to unmarried mothers: Childhood living arrangements and young adult outcomes. Journal of Marriage and Family 58(2): 293-310. doi:10.2307/353496.

Astone, N.M., Nathanson, C.A., Schoen, R., and Kim, Y.J. (1999). Family demography, social theory, and investment in social capital. Population and Development Review 25(1): 1-31. doi:10.1111/j.1728-4457.1999.00001.x.

Augustine, J.M. and Raley, R.K. (2013). Multigenerational households and the school readiness of children born to unmarried mothers. Journal of Family Issues 34(4): 431-459. doi:10.1177/0192513X12439177.

Baron, R.M. and Kenny, D.A. (1986). The moderator-mediator variable distinction in social psychological research: Conceptual, strategic, and statistical considerations. Journal of Personality and Social Psychology 51(6): 1173-1182. doi:10.1037/0022-3514.51.6.1173. 
Bierman, K.L., Coie, J.D., Dodge, K.A., Greenberg, M.T., Lochman, J.E., McMahon, R.J., and Pinderhughes, E. (2010). The effects of a multiyear universal socialemotional learning program: The role of student and school characteristics. Journal of Consulting and Clinical Psychology 78(2): 156-168. doi:10.1037/ a0018607.

Braver, S.L., Griffin, W.A., and Cookston, J.T. (2005). Prevention programs for divorced nonresident fathers. Family Court Review 43(1): 81-96. doi:10.1111/ j.1744-1617.2005.00009.x.

Britto, P.R., Lye, S.J., Proulx, K., Yousafzai, A.K., Matthews, S.G., Vaivada, T., PerezEscamilla, R., Rao, N., Ip, P., Fernald, L.C.H., MacMillan, H., Hanson, M., Wachs, T.D., Yao, H., Yoshikawa, H., Cerezo, A., Leckman, J.F., Bhutta, Z.A., and the Early Childhood Development Interventions Review Group (2016). Nurturing care: Promoting early childhood development. The Lancet 389(10064): 91-102. doi:10.1016/S0140-6736(16)31390-3.

Cabrera, N., Fitzgerald, H.E., Bradley, R.H., and Roggman, L. (2007). Modeling the dynamics of paternal influences on children over the life course. Applied Development Science 11(4): 185-189. doi:10.1080/10888690701762027.

Carlson, M., McLanahan, S., and England, P. (2004). Union formation in fragile families. Demography 41(2): 237-261. doi:10.1353/dem.2004.0012.

Cavanagh, S.E. and Huston, A.C. (2006). Family instability and children's early problem behavior. Social Forces 85(1): 551-581. doi:10.1353/sof.2006.0120.

Centro Microdatos (2013). Presentacion: Segunda ronda encuesta longitudinal de la primera infancia. Santiago: Departamento de Economia, Universidad de Chile.

Chetty, R., Friedman, J.N., Hilger, N., Saez, E., Schanzenbach, D.W., and Yagan, D. (2011). How does your kindergarten classroom affect your earnings? Evidence from Project Star. The Quarterly Journal of Economics 126(4): 1593-1660. doi:10.1093/qje/qjr041.

Coleman, M., Ganong, L., and Fine, M.A. (2000). Reinvestigating remarriage: Another decade of progress. Journal of Marriage and Family 62(4): 1288-1307. doi:10.1111/j.1741-3737.2000.01288.x.

Contreras, D. and González, S. (2015). Determinants of early child development in Chile: Health, cognitive and demographic factors. International Journal of Educational Development 40: 217-230. doi:10.1016/j.ijedudev.2014.06.010. 
Cooper, C.E., McLanahan, S.S., Meadows, S.O., and Brooks-Gunn, J. (2009). Family structure transitions and maternal parenting stress. Journal of Marriage and Family 71(3): 558-574. doi:10.1111/j.1741-3737.2009.00619.x.

Corina, S.V. (2008). El Child Behavior Checklist: Su estandarización en población urbana Argentina. Revista de Psicología 4(8): 113-130.

Crookston, B.T., Schott, W., Cueto, S., Dearden, K.A., Engle, P., Georgiadis, A., Lundeen, E.A., Penny, M.E., Stein, A.D., and Behrman, J.R. (2013). Postinfancy growth, schooling, and cognitive achievement: Young lives. The American Journal of Clinical Nutrition 98(6): 1555-1563. doi:10.3945/ajen.113.067561.

Curtin, S.C., Ventura, S.J., and Martinez, G.M. (2014). Recent declines in nonmarital childbearing in the United States. Washington, D.C.: US Department of Health and Human Services, Centers for Disease Control and Prevention, National Center for Health Statistics (NCHS Data Brief No. 162). http://s3.documentcloud.org/documents/1273985/births.pdf.

Deleire, T. and Kalil, A. (2002). Good things come in threes: Single-parent multigenerational family structure and adolescent adjustment. Demography 39(2): 393-413. doi:10.1353/dem.2002.0016.

Di Manno, L., Macdonald, J.A., and Knight, T. (2015). Family dissolution and offspring depression and depressive symptoms: A systematic review of moderation effects. Journal of Affective Disorders 188(Supplement C): 68-79. doi:10.1016/j.jad.2015.08.017.

Duflo, E. (2003). Grandmothers and granddaughters: Old-age pensions and intrahousehold allocation in South Africa. The World Bank Economic Review 17(1): 1-25. doi:10.1093/wber/lhg013.

Dunifon, R.E., Ziol-Guest, K.M., and Kopko, K. (2014). Grandparent coresidence and family well-being implications for research and policy. The Annals of the American Academy of Political and Social Science 654(1): 110-126. doi:10.1177/0002716214526530.

Dunifon, R. and Kowaleski-Jones, L. (2007). The influence of grandparents in singlemother families. Journal of Marriage and Family 69(2): 465-481. doi:10.1111/ j.1741-3737.2007.00377.x.

Dunn, L.M., Padilla, E.R., Lugo, D.E., and Dunn, L.M. (1986). Manual del examinador para el test de vocabulario en imágenes Peabody. Circle Pines: American Guidance Service. 
Engle, P.L., Black, M.M., Behrman, J.R., Cabral de Mello, M., Gertler, P.J., Kapiriri, L., Martorell, R., Young, M.E., and the International Child Development Steering Group (2007). Strategies to avoid the loss of developmental potential in more than 200 million children in the developing world. The Lancet 369(9557): 229-242. doi:10.1016/S0140-6736(07)60112-3.

Engle, P.L., Fernald, L.C.H., Alderman, H., Behrman, J., O'Gara, C., Yousafzai, A.K., Cabral de Mello, M., Hidrobo, M., Ulkuer, N., Ertem, I., Iltus, S., and the Global Child Development Steering Group (2011). Strategies for reducing inequalities and improving developmental outcomes for young children in low-income and middle-income countries. The Lancet 378(9799): 1339-1353. doi:10.1016/S0 140-6736(11)60889-1.

Fernald, L.C.H., Weber, A., Galasso, E., and Ratsifandrihamanana, L. (2011). Socioeconomic gradients and child development in a very low income population: Evidence from Madagascar. Developmental Science 14(4): 832-847. doi:10.1111/j.1467-7687.2010.01032.x.

Foster, E.M. and Kalil, A. (2007). Living arrangements and children's development in low-income white, black, and latino families. Child Development 78(6): 16571674. doi:10.1111/j.1467-8624.2007.01091.x.

Gertler, P., Heckman, J., Pinto, R., Zanolini, A., Vermeersch, C., Walker, S., Chang, S.M., and Grantham-McGregor, S. (2014). Labor market returns to an early childhood stimulation intervention in Jamaica. Science 344(6187): 998-1001. doi:10.1126/science. 1251178 .

Heckman, J.J., Stixrud, J., and Urzua, S. (2006). The effects of cognitive and noncognitive abilities on labor market outcomes and social behavior. Journal of Labor Economics 24(3): 411-482. doi:10.3386/w12006.

Hetherington, E.M., Bridges, M., and Insabella, G.M. (1998). What matters? What does not? Five perspectives on the association between marital transitions and children's adjustment. Annual Progress in Child Psychiatry and Child Development 53(2): 167-184. doi:10.1037/0003-066X.53.2.167.

Hicks, R. and Tingley, D. (2011). Causal mediation analysis. Stata Journal 11(4): 605619.

Imai, K., Keele, L., and Tingley, D. (2010). A general approach to causal mediation analysis. Psychological Methods 15(4): 309-334. doi:10.1037/a0020761. 
Kurdek, L.A., Fine, M.A., and Sinclair, R.J. (1995). School adjustment in sixth graders: Parenting transitions, family climate, and peer norm effects. Child Development 66(2): 430-445. doi:10.1111/j.1467-8624.1995.tb00881.x.

McLanahan, S., Tach, L., and Schneider, D. (2013). The causal effects of father absence. Annual Review of Sociology 39: 399-427. doi:10.1146/annurev-soc071312-145704.

Mikulincer, M., Shaver, P.R., and Pereg, D. (2003). Attachment theory and affect regulation: The dynamics, development, and cognitive consequences of attachment-related strategies. Motivation and Emotion 27(2): 77-102. doi:10.1023/A:1024515519160.

Mollborn, S., Fomby, P., and Dennis, J.A. (2010). Who matters for children's early development? Race/ethnicity and extended household structures in the United States. Child Indicators Research 4(3): 389-411. doi:10.1007/s12187-010-90902 .

Monserud, M.A. and Elder, G.H. (2011). Household structure and children's educational attainment: A perspective on coresidence with grandparents. Journal of Marriage and Family 73(5): 981-1000. doi:10.1111/j.1741-3737.2011. 00858.x.

Moreno, C.H.G. and Sandoval, A.A.M. (2015). Mujer, madre y abuela, la fusión de los roles. Rumbos TS 12: 48-68.

Mutchler, J.E. and Baker, L.A. (2009). The implications of grandparent coresidence for economic hardship among children in mother-only families. Journal of Family Issues 30(11): 1576-1597. doi:10.1177/0192513X09340527.

Osborne, C. and McLanahan, S. (2007). Partnership instability and child well-being. Journal of Marriage and Family 69(4): 1065-1083. doi:10.1111/j.1741-3737. 2007.00431.x.

Page, M.E. and Stevens, A.H. (2004). The economic consequences of absent parents. The Journal of Human Resources 39(1): 80-107. doi:10.2307/3559006.

Pilkauskas, N.V. (2014). Living with a grandparent and parent in early childhood: Associations with school readiness and differences by demographic characteristics. Developmental Psychology 50(12): 2587-2599. doi:10.1037/ a0038179. 
Pleck, J.H. (2007). Why could father involvement benefit children? Theoretical perspectives. Applied Development Science 11(4): 196-202. doi:10.1080/1088 8690701762068.

Ponczek, V. (2011). Income and bargaining effects on education and health in Brazil. Journal of Development Economics 94(2): 242-253. doi:10.1016/j.jdeveco. 2010.01.011.

Pong, S.-L. and Chen, V.W. (2010). Co-resident grandparents and grandchildren's academic performance in Taiwan. Journal of Comparative Family Studies 41(1): 111-129.

Rebolledo, L. (2008). Del padre ausente al padre próximo: Emergencia de nuevas formas de paternidad en el Chile actual. In: Araujo, K. and Prieto, M. (eds.). Estudios sobre sexualidades en América Latina. Quito: FLACSO: 123-140.

Ruggles, S. and Heggeness, M. (2008). Intergenerational coresidence in developing countries. Population and Development Review 34(2): 253-281. doi:10.1111/j. 1728-4457.2008.00219.x.

Ryan, R.M. and Claessens, A. (2013). Associations between family structure changes and children's behavior problems: The moderating effects of timing and marital birth. Developmental Psychology 49(7): 1219-1231. doi:10.1037/a0029397.

Salinas, V. (2011). Socioeconomic differences according to family arrangements in Chile. Population Research and Policy Review 30(5): 677-699.

Schady, N., Behrman, J.R., Araujo, M.C., Azuero, R., Bernal, R., Bravo, D., López Bóo, F., Macours, K., Mashall, D., Paxson, C., and Vakis, R. (2015). Wealth gradients in early childhood cognitive development in five Latin American countries. Journal of Human Resources 50(2): 446-463. doi:10.3368/jhr.50. 2.446 .

Schmeer, K.K. (2013). Family structure and child anemia in Mexico. Social Science and Medicine 95: 16-23. doi:10.1016/j.socscimed.2012.10.028.

Schott, W., Aurino, E., Penny, M.E., and Behrman, J.R. (2017). Adolescent mothers' anthropometrics and grandmothers' schooling predict infant anthropometrics in Ethiopia, India, Peru, and Vietnam. Annals of the New York Academy of Sciences. doi:10.1111/nyas.13455.

The World Bank (2014). Labor force participation rate, female (\% of female population ages 15+) [electronic resource]. Washington, D.C.: The World Bank. http://data.worldbank.org/indicator/SL.TLF.CACT.FE.ZS/. 
Thomson, E., Hanson, T.L., and McLanahan, S.S. (1994). Family structure and child well-being: Economic resources vs. parental behaviors. Social Forces 73(1): 221-242. doi:10.1093/sf/73.1.221.

UNdata (2015). Life expectancy at birth, females [electronic resource]. New York: United Nations Statistics Division. http://data.un.org/Data.aspx?d=PopDiv\&f $=$ variableID $\% 3 \mathrm{~A} 67$.

United Nations, Department of Economic and Social Affairs, Population Division (2015). World fertility data 2015 [electronic resource]. New York: United Nations. http://www.un.org/en/development/desa/population/publications/data set/fertility/wfd2015.shtml.

Valdés, X. (2009). El lugar que habita el padre en Chile contemporáneo: Estudio de las representaciones sobre la paternidad en distintos grupos sociales. Polis, Revista de La Universidad Bolivariana 8(23): 385-410. doi:10.4067/S0718-65682009 000200017.

Viola, L., Garrido, G., and Rescorla, L. (2011). Testing multicultural robustness of the Child Behavior Checklist in a national epidemiological sample in Uruguay. Journal of Abnormal Child Psychology 39(6): 897-908. doi:10.1007/s10802011-9500-z.

Walker, S.P., Chang, S.M., Vera-Hernández, M., and Grantham-McGregor, S. (2011). Early childhood stimulation benefits adult competence and reduces violent behavior. Pediatrics 127(5): 849-857. doi:10.1542/peds.2010-2231.

Zeng, Z. and Xie, Y. (2014). The effects of grandparents on children's schooling: Evidence from rural China. Demography 51(2): 599-617. doi:10.1007/s13524013-0275-4. 


\section{Appendix: Supplemental data on trends in household structure}

Using Chile's nationally representative cross-sectional household survey CASEN from 2003, 2006, and 2011 (Ministerio de Desarrollo Social), we examined trends in household structure for mothers of young children over a longer time period than allowed for with the ELPI (Figure A-1). The 2003 CASEN survey had slightly less detail about relationships in the household, only indicating if an individual was child of the head, but the 2006 and 2011 surveys indicate if the individual was child of head and spouse, child of head only, or child of spouse only. Comparing the fractions in the 2011 portion of the graph in Figure A1 to those fractions reflected by the 2010 families in the column "Total" from Table 1, there were more single mothers and fewer threegenerational households than in the 2010 ELPI survey. This, in part, may be because we did not include paternal grandparents in the CASEN tally because these were more difficult to identify using the household roster. Trends indicated the incidence of single motherhood rose between 2003 and 2011. The legalization of divorce in 2004 could have been a contributing factor. We note that this trend suggests that in the future more children will be living without fathers and grandparents. We also note that the fraction of mothers living with their own parents has stayed relatively constant over time, revealing the permanence of the three-generational household structure in Chile.

Figure A-1: Percentage of mothers in different household arrangements

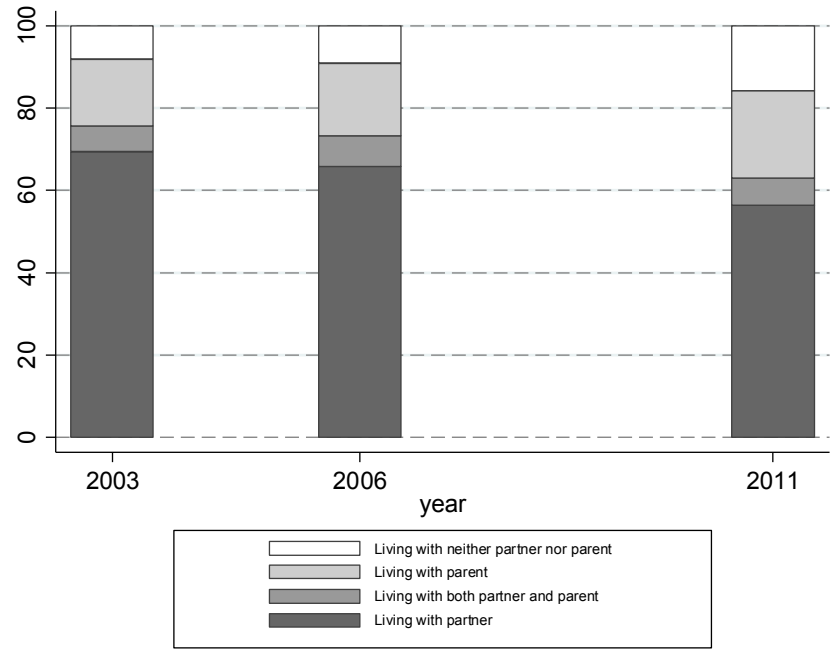

Source: CASEN.

Note: Mothers with at least one child aged 6 years or younger. 
Reynolds et al.: Family structure and child development in Chile

\section{Table A-1: Attrition analysis}

\begin{tabular}{|c|c|c|c|c|c|c|c|c|c|c|}
\hline & \multirow[b]{3}{*}{ Variable means $\mathrm{N}$} & \multicolumn{3}{|c|}{$\begin{array}{l}>=30 \text { months in } 2010 \\
\text { (TVIP) }\end{array}$} & \multicolumn{3}{|c|}{$\begin{array}{l}>17 \&<49 \text { months in } \\
2010 \text { (CBCL) }\end{array}$} & \multicolumn{3}{|c|}{ All children (income) } \\
\hline & & $\begin{array}{l}\text { Both } \\
\text { years } \\
\text { available }\end{array}$ & $\begin{array}{l}\text { Only } \\
2010\end{array}$ & $\begin{array}{l}\mathrm{p} \text {-value } \\
\text { difference }\end{array}$ & $\begin{array}{l}\text { Both } \\
\text { years } \\
\text { available }\end{array}$ & $\begin{array}{l}\text { Only } \\
2010\end{array}$ & $\begin{array}{l}\mathrm{p} \text {-value } \\
\text { difference }\end{array}$ & $\begin{array}{l}\text { Both } \\
\text { years } \\
\text { available }\end{array}$ & $\begin{array}{l}\text { Only } \\
2010\end{array}$ & $\begin{array}{l}\mathrm{p} \text {-value } \\
\text { difference }\end{array}$ \\
\hline & & 7,021 & 1,328 & & 8,515 & 1,350 & & 12,898 & 2,277 & \\
\hline \multirow{4}{*}{$\begin{array}{l}\text { Household } \\
\text { structure }\end{array}$} & $\begin{array}{l}\text { Child's grandparent } \\
\text { present in household }\end{array}$ & 0.36 & 0.30 & 0.00 & 0.37 & 0.33 & 0.00 & 0.38 & 0.33 & 0.00 \\
\hline & $\begin{array}{l}\text { Child's father present } \\
\text { in household }\end{array}$ & 0.68 & 0.68 & 0.80 & 0.68 & 0.67 & 0.54 & 0.68 & 0.69 & 0.67 \\
\hline & $\begin{array}{l}\text { Both child's father \& } \\
\text { grandparent present }\end{array}$ & 0.14 & 0.11 & 0.00 & 0.15 & 0.13 & 0.08 & 0.15 & 0.13 & 0.00 \\
\hline & $\begin{array}{l}\text { Neither child's father } \\
\text { nor grandparent } \\
\text { present }\end{array}$ & 0.10 & 0.13 & 0.00 & 0.09 & 0.12 & 0.00 & 0.09 & 0.11 & 0.00 \\
\hline \multirow{6}{*}{$\begin{array}{l}\text { Child } \\
\text { variables }\end{array}$} & $\begin{array}{l}\text { Vocabulary Score } \\
\text { (TVIP) }\end{array}$ & 99.99 & 100.08 & 0.86 & 100.07 & 99.56 & 0.38 & 99.99 & 100.08 & 0.86 \\
\hline & $\begin{array}{l}\text { Externalizing Behavior } \\
\text { Score }(\mathrm{CBCL})\end{array}$ & 99.73 & 101.38 & 0.00 & 99.74 & 101.67 & 0.00 & 99.74 & 101.67 & 0.00 \\
\hline & Female & 0.50 & 0.49 & 0.71 & 0.50 & 0.48 & 0.32 & 0.49 & 0.49 & 0.49 \\
\hline & Age in months & 41.11 & 41.16 & 0.83 & 32.86 & 32.42 & 0.09 & 30.50 & 30.26 & 0.44 \\
\hline & $\begin{array}{l}\text { Ever enrolled in } \\
\text { preschool }\end{array}$ & 0.64 & 0.65 & 0.39 & 0.48 & 0.55 & 0.00 & 0.46 & 0.50 & 0.00 \\
\hline & $\begin{array}{l}\text { Grandmother } \\
\text { Caregiver (2010) }\end{array}$ & 0.17 & 0.15 & 0.05 & 0.16 & 0.15 & 0.34 & 0.16 & 0.15 & 0.14 \\
\hline \multirow{7}{*}{$\begin{array}{l}\text { Mother } \\
\text { variables }\end{array}$} & $\begin{array}{l}\text { Mother employed } \\
\text { (2010) }\end{array}$ & 0.45 & 0.47 & 0.07 & 0.42 & 0.45 & 0.01 & 0.42 & 0.45 & 0.00 \\
\hline & Age at first birth & 22.56 & 23.00 & 0.01 & 22.43 & 22.77 & 0.03 & 22.40 & 22.98 & 0.00 \\
\hline & Math ability score & 99.72 & 101.67 & 0.00 & 99.73 & 101.68 & 0.00 & 99.68 & 102.03 & 0.00 \\
\hline & $\begin{array}{l}\text { Vocabulary ability } \\
\text { score }\end{array}$ & 99.79 & 101.47 & 0.00 & 99.68 & 101.93 & 0.00 & 99.69 & 101.99 & 0.00 \\
\hline & $\begin{array}{l}\text { Primary education } \\
\text { only completed }\end{array}$ & 0.19 & 0.14 & 0.00 & 0.19 & 0.16 & 0.03 & 0.18 & 0.15 & 0.00 \\
\hline & $\begin{array}{l}\text { Secondary education } \\
\text { but no tertiary }\end{array}$ & 0.58 & 0.54 & 0.00 & 0.59 & 0.54 & 0.00 & 0.59 & 0.54 & 0.00 \\
\hline & Indigenous & 0.08 & 0.08 & 0.69 & 0.08 & 0.09 & 0.26 & 0.08 & 0.09 & 0.57 \\
\hline \multirow{3}{*}{$\begin{array}{l}\text { Household } \\
\text { variables }\end{array}$} & Number of siblings & 0.99 & 0.93 & 0.04 & 0.95 & 0.92 & 0.36 & 0.94 & 0.89 & 0.05 \\
\hline & Urban & 0.89 & 0.94 & 0.00 & 0.89 & 0.93 & 0.00 & 0.90 & 0.93 & 0.00 \\
\hline & Log per capita income & 4.94 & 5.11 & 0.00 & 4.93 & 5.09 & 0.00 & 4.93 & 5.10 & 0.00 \\
\hline \multicolumn{2}{|c|}{$\begin{array}{l}P \text {-value of } F \text { test of joint significance } \\
\text { of all variables in a logit regression } \\
\text { with attrition as outcome }\end{array}$} & & & 0.00 & & & 0.00 & & & 0.00 \\
\hline
\end{tabular}

Notes: 'Both years available' means child has survey responses in both rounds; outcomes \& covariates could be missing. The age window for administering the Peabody Picture Test is 30 months or more.

The age window of the CBCL is $18-72$ months. All children are under 72 months in round 1 .

Round 2 occurred $\sim 2$ years after round 1 . To not have aged out of the CBCL window in round 2 , children had to be less than 48 months in round 1.

Because the time between round 1 and round 2 is not always an exact two years, the attrition analysis for the CBCL is approximate. 


\section{Table A-2: Logistic regression to generate inverse probability weights}

\begin{tabular}{|c|c|c|}
\hline & & Non-attriter \\
\hline \multirow{5}{*}{ Household structure } & \multirow{2}{*}{ Child's grandparent present in household } & $0.445^{* *}$ \\
\hline & & $(0.106)$ \\
\hline & \multirow{2}{*}{ Child's father present in household } & $0.207^{*}$ \\
\hline & & $(0.093)$ \\
\hline & Interaction: Child's father $\mathrm{x}$ grandparent present & $\begin{array}{c}-0.241+ \\
(0.130)\end{array}$ \\
\hline \multirow{7}{*}{ Child variables } & \multirow{2}{*}{ Female } & 0.027 \\
\hline & & $(0.049)$ \\
\hline & \multirow{2}{*}{ Age in months } & 0.006 ** \\
\hline & & $(0.002)$ \\
\hline & \multirow{2}{*}{ Ever enrolled in preschool (2010) } & -0.231 ** \\
\hline & & $(0.055)$ \\
\hline & Grandmother caregiver (2010) & $\begin{array}{l}0.148+ \\
(0.081)\end{array}$ \\
\hline \multirow{10}{*}{ Mother variables } & \multirow{2}{*}{ Mother's age at first birth } & -0.001 \\
\hline & & $(0.006)$ \\
\hline & \multirow{2}{*}{ Mother employed (2010) } & -0.009 \\
\hline & & $(0.057)$ \\
\hline & \multirow{2}{*}{ Primary education only completed } & $0.437^{* *}$ \\
\hline & & $(0.090)$ \\
\hline & \multirow{2}{*}{ Secondary education but no tertiary } & 0.379 ** \\
\hline & & $(0.072)$ \\
\hline & \multirow{2}{*}{ Indigenous } & -0.155 \\
\hline & & $(0.099)$ \\
\hline \multirow{8}{*}{ Household variables } & \multirow{2}{*}{ Number of siblings } & $0.049+$ \\
\hline & & $(0.029)$ \\
\hline & \multirow{2}{*}{ Urban } & -0.349 * \\
\hline & & $(0.160)$ \\
\hline & \multirow{2}{*}{ constant } & 1.516 ** \\
\hline & & $(0.254)$ \\
\hline & $\mathrm{N}$ & 13,793 \\
\hline & pseudo- $R^{2}$ & 0.012 \\
\hline
\end{tabular}

Notes: Data values from 2010. Mother intelligence scores and household income were omitted as they had the largest number missing. Robust standard errors clustered by municipality. 
Reynolds et al.: Family structure and child development in Chile

Table A-3: Summary statistics by household transition status between 2010 and 2012

\begin{tabular}{|c|c|c|c|c|}
\hline & Variable & $\begin{array}{l}\text { Stable } \\
\text { mean }\end{array}$ & $\begin{array}{l}\text { Transitioned } \\
\text { mean }\end{array}$ & p-value ${ }^{\star}$ \\
\hline \multirow{8}{*}{ Child variables } & Vocabulary score (TVIP 2010) & 100.07 & 99.60 & 0.38 \\
\hline & Vocabulary score (TVIP 2012) & 100.27 & 99.30 & 0.02 \\
\hline & Behavior score (CBCL 2010) & 100.14 & 97.73 & 0.00 \\
\hline & Behavior score (CBCL 2012) & 100.26 & 98.87 & 0.00 \\
\hline & Female & 0.50 & 0.48 & 0.27 \\
\hline & Age in months (2010) & 30.63 & 29.52 & 0.00 \\
\hline & Grandmother caregiver (2010) & 0.45 & 0.47 & 0.15 \\
\hline & Ever attended preschool (2010) & 0.15 & 0.20 & 0.00 \\
\hline \multirow{7}{*}{$\begin{array}{c}\text { Mother } \\
\text { variables }\end{array}$} & Mother's age at first birth & 22.63 & 21.34 & 0.00 \\
\hline & Mother employed (2010) & 0.42 & 0.42 & 0.87 \\
\hline & Mother's math ability score (WAIS) & 99.74 & 99.68 & 0.87 \\
\hline & Mother's vocabulary ability score (WAIS) & 99.83 & 98.85 & 0.01 \\
\hline & Primary education only completed & 0.18 & 0.17 & 0.06 \\
\hline & Secondary education but no tertiary & 0.59 & 0.64 & 0.00 \\
\hline & Indigenous & 0.08 & 0.09 & 0.40 \\
\hline \multirow{5}{*}{$\begin{array}{c}\text { Household } \\
\text { variables }\end{array}$} & Number of siblings & 0.97 & 0.78 & 0.00 \\
\hline & Urban & 0.89 & 0.91 & 0.00 \\
\hline & Log per capita income (2010) & 4.96 & 4.82 & 0.00 \\
\hline & Log per capita income (2012) & 5.18 & 5.13 & 0.02 \\
\hline & $\mathrm{N}($ Total $\mathrm{N}=10,813)$ & 1,893 & 8,920 & \\
\hline
\end{tabular}

Notes: *from t-test of difference in means

Vocabulary is standardized (mean 0; sd 15) score on the Spanish version of the Peabody Picture Vocabulary Test

Behavior is standardized (mean 0; sd 15) score on the Child Behavior Checklist

Income is log per capita income in Chilean pesos/500 1US\$2010-2012 ELPI - sample defined by children with complete controls \& test score/income data.

\section{Table A-4: Rates of select variables at baseline and changes between 2010 and 2012 by transition type}

\begin{tabular}{|c|c|c|c|c|c|c|c|c|c|c|}
\hline \multirow[b]{2}{*}{ Variable (percent) } & \multicolumn{2}{|c|}{$\begin{array}{l}\text { Grandparents } \\
\text { separate }\end{array}$} & \multicolumn{2}{|l|}{$\begin{array}{l}\text { Father } \\
\text { joins }\end{array}$} & \multicolumn{2}{|l|}{$\begin{array}{l}\text { Father } \\
\text { exits }\end{array}$} & \multicolumn{2}{|c|}{$\begin{array}{l}\text { No transition } \\
\text { (Extended) }\end{array}$} & \multicolumn{2}{|c|}{$\begin{array}{l}\text { No transition } \\
\text { (Nuclear) }\end{array}$} \\
\hline & 2010 & $2012-10$ & 2010 & $2012-10$ & 2010 & $2012-10$ & 2010 & $2012-10$ & 2010 & $2012-10$ \\
\hline Mother employed & $40 \%$ & $8 \%$ & $43 \%$ & $3 \%$ & $43 \%$ & $14 \%$ & $41 \%$ & $9 \%$ & $39 \%$ & $5 \%$ \\
\hline $\begin{array}{l}\text { Grandparent primary } \\
\text { caregiver }\end{array}$ & $24 \%$ & $-5 \%$ & $25 \%$ & $-4 \%$ & $14 \%$ & $10 \%$ & $28 \%$ & $5 \%$ & $11 \%$ & $1 \%$ \\
\hline \multirow[t]{2}{*}{ Child attends preschool } & $42 \%$ & $45 \%$ & $42 \%$ & $43 \%$ & $48 \%$ & $41 \%$ & $41 \%$ & $43 \%$ & $40 \%$ & $45 \%$ \\
\hline & $N=853$ & & $N=499$ & & $N=588$ & & $N=2,573$ & & $N=5,85$ & \\
\hline
\end{tabular}

Source: ELPI 2010 \& 2012.

Note: Sample defined by children with complete controls, income data, and information on these supplemental variables. 